Netspar

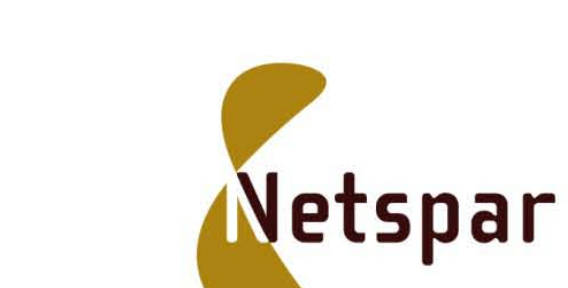

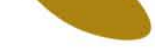

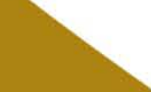

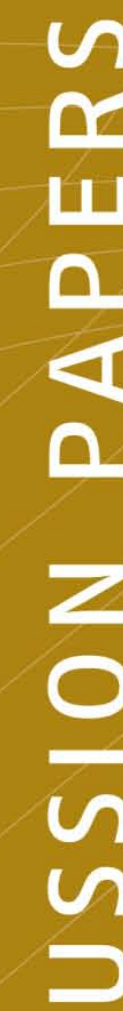

Marleen Damman, Kène Henkens and Matthijs Kalmijn

U Do Older Workers Develop a Short-

Timer's Attitude Prior to Retirement?

Evidence from a Panel Study

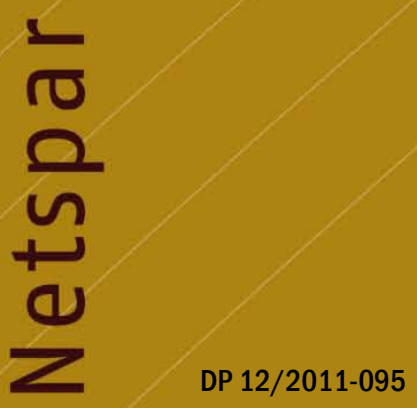




\title{
Do Older Workers Develop a Short-timer's Attitude Prior to Retirement?
}

\section{Evidence from a Panel Study}

\author{
Marleen Damman*, Kène Henkens*o, Matthijs Kalmijnº
}

* Netherlands Interdisciplinary Demographic Institute (NIDI), The Hague, The Netherlands

○ Tilburg University, Department of Sociology, Tilburg, The Netherlands

Correspondence to:

Marleen Damman, damman@nidi.nl

NIDI, P.O. Box 11650, 2502 AR The Hague, The Netherlands 


\section{ABSTRACT (200 words)}

Objectives. Even though in retirement and career theories reference is made to a preretirement work disengagement process among older workers, quantitative empirical knowledge about this process is limited. The aim of this study is to improve our understanding of work disengagement in the preretirement period, by examining the impact of proximity to planned retirement (anticipated future) and work, educational, and health experiences (lived past) on preretirement work disengagement.

Methods. Using panel data of Dutch older workers, a scale was developed to measure the hypothesized reductions in work investments, activities, and motivation (i.e., disengagement) in preretirement years. We estimated linear regression models (cross-sectional analyses; $\mathrm{N}=1634$ ) and conditional change models (panel analyses; $\mathrm{N}=652$ ) to examine the preretirement work disengagement process.

Results. In line with the notion of the preretirement disengagement process, this study shows that many older employees disengage more from work when getting closer to their planned retirement age. Career experiences of promotion and employer change slow down the disengagement process. Declining health, in contrast, accelerates the process.

Discussion. For achieving a comprehensive understanding of the retirement process, not only past and present experiences, but also the anticipated future (i.e., expected time-left in the current state) should be taken into account.

Key-words: Life course - Older workers - Preretirement process - Work history 


\section{INTRODUCTION}

Retirement can be perceived as a complex long-term process, which encompasses preretirement anticipation of retirement, the retirement act itself, and postretirement adjustment to new conditions (Beehr, 1986; Shultz \& Wang, 2011; Wang \& Shultz, 2010). In the preretirement period older workers will plan and prepare for retirement (see for review Adams \& Rau, 2011), but can also be expected to gradually reduce their work investments, activities, and motivation (i.e., to disengage from their work). Atchley (1976) described that employees may develop a “short-timer’s attitude” during the phase near retirement (p.67). Also in the traditional career stage theory of Super (1957), late careers are portrayed as a period of maintenance followed by a period of decline, which is proposed to be "a period of tapering off of activities, of slowing down and cutting out” (Super, 1957, p.154). Even though given policy measures to keep workers in the labor force until older ages (OECD, 2006) insights in late-career work disengagement are highly relevant, few studies have attempted to provide the notion of preretirement work disengagement with a theoretical and empirical basis. This study aims at filling this gap, by studying the following questions: (1) Is there a preretirement work disengagement process and (2) How is this process influenced by careerrelated experiences?

In exploratory qualitative studies, reference has been made to work disengagement of employees in preretirement years. About two-third of the state employees interviewed by McEvoy and Blahna (2001) mentioned older workers’ disengagement as a problem. Based on qualitative interviews with managers Henkens and Van Solinge (2003) conclude that many managers can name examples of disengaged older workers in the phase near retirement. They are referred to as "mentally retired” persons or "employees who already have disconnected themselves” (p.80). Quantitative studies on age and job attitudes do not seem to reflect this picture of disengaged workers in preretirement years though: A recent meta-analysis shows 
that older workers generally have more favorable job attitudes than younger workers $(\mathrm{Ng} \&$ Feldman, 2010). However, in a study in which job attitudes are not only examined along the time dimension of 'age', but also along the dimension of 'proximity to retirement' (Ekerdt \& DeViney, 1993), support has been found for the notion of preretirement work disengagement. When controlling for age, the study shows that older workers feel more nervous and tired when they are closer to their anticipated retirement age. The authors conclude that: "With the greener grass of retirement in view, older workers are free to admit doubts about the quality and demands of their jobs” (Ekerdt \& DeViney, 1993, p. S41).

This study will contribute to the literature on retirement anticipation in two ways. First, as Ekerdt and DeViney (1993) note, not only attitudes about the burdensomeness of jobs can change in anticipation of retirement, but also behaviors, relationships and other job-related attitudes. To improve our understanding of the preretirement work disengagement process we developed a broad measure of preretirement work disengagement that focuses - in line with the descriptions by Atchley (1976) and Super (1957) - on (preferred) reductions in work investments, work motivation, and work activities. The scale captures various attitudes and behaviors older workers specifically can be expected to change in their preretirement period. For example, items of the scale comprise the willingness to participate in new courses, preferred reductions of work hours, and attitudes about the assignment of responsibilities to younger workers.

Second, we will not only study the impact of time-left to retirement (anticipated future) on work disengagement, but also examine the impact of previous career experiences (lived past). The life course proposition of lifelong development suggests that life periods should be understood "within the context of a lived past and anticipated future" (Settersten, 2003, p.37). Since career plateauing is a key career issue related to the latter years of work (Bown-Wilson \& Parry, 2009), one aspect of the "lived past" that might be relevant for understanding work 
disengagement is previous career mobility. Also past experiences in the educational and health spheres are expected to be of importance for understanding preretirement work disengagement. Past career experiences have been shown to be of importance for explaining retirement planning (Moen, Sweet, \& Swisher, 2005), retirement timing (e.g., Damman, Henkens, \& Kalmijn, 2011; Han \& Moen, 1999; Hank, 2004; Hayward, Friedman, \& Chen, 1998; Raymo, Warren, Sweeney, Hauser, \& Ho, 2011) and postretirement employment (Singh \& Verma, 2003). To what extent and how these experiences are also relevant predictors of preretirement work disengagement, is yet still largely unknown.

This article is based on two-wave panel data collected in 2001 and 2006-2007 among Dutch workers of ages 50 to 64 (at wave 1). At both points in time we measured preretirement work disengagement. Therefore, we can study both individual differences in the level of work disengagement in late careers (cross-section), and changes in disengagement over time (panel). Especially for examining the effect of proximity to retirement on work disengagement the availability of panel data is important, given that causality may run in both directions (Ekerdt \& DeViney, 1993). Information about the planned retirement age was collected at baseline, which offers the opportunity to study whether workers who almost reached their previously reported retirement age at wave 2 experience larger increases of disengagement over the studied period than workers who still have many years left in the labor force.

\section{THEORY AND HYPOTHESES}

From a life course perspective it is expected that individuals make choices and take actions within the opportunities and constraints of their social worlds (Elder \& Johnson, 2003; Settersten, 2003). In line with this proposition of 'human agency within structure,' older workers can be expected to vary in their levels of preretirement work disengagement, according to their opportunity structure in the preretirement period and the associated 
perceived costs and returns of work activities and investments. Given that both anticipated future career experiences and past career experiences will shape the individual opportunity structure in the preretirement period, these experiences can be hypothesized to affect preretirement work disengagement.

\section{Anticipated future career}

During the $20^{\text {th }}$ century retirement has become an institution. State-funded old age security regulations, employer pensions, and social norms about retirement have resulted in an established pattern of most workers leaving the labor force between ages 55 and 65 (Szinovacz, 2003). Given this institutionalization of the retirement transition, "the eventuality of retirement is a socially structured given with which people must cope and toward which they devise actions to be taken” (Ekerdt, Kosloski, \& DeViney, 2000, p.4). From a sociological viewpoint, the institutionalized life course transition of retirement can be expected to be accompanied "with its own socialization and transition procedures" (Evans, Ekerdt, \& Bossé, 1985, p.373). In the phase near retirement individuals will start to accommodate themselves to the upcoming separation from their work and the accompanying social situation (Atchley, 1976). To prevent a disruptive transition from work to retirement, employees can be expected to gradually disengage from their work. Findings on retirement adaptation also suggest the existence of a preretirement process (Evans et al., 1985). Most retirees seem to adjust to retirement very quickly (Van Solinge \& Henkens, 2005), which might indicate that individuals already started their adjustment process prior to the actual retirement transition. When taking an economic perspective, a preretirement work disengagement process can be expected as well. The diminishing time-left in the labor market will restrict the payback period of work activities and investments, which might reduce the amount of activities and investments the employee is willing to make. We hypothesize that 
the closer older employees get to their planned retirement age, the higher their level of preretirement work disengagement is (Hypothesis 1).

\section{Past career experiences}

As individuals age, they change jobs less frequently and are more likely to experience hierarchical plateauing (Allen, Russell, Poteet, \& Dobbins, 1999). Work disengagement can be expected to be related to these prior career experiences - such as position changes, promotions, and employer changes - because they will affect the opportunity structure in preretirement years. A change of position can be expected to result in a work situation that more closely fits with the employees' needs and expectations. Making promotion will cause an improvement of working conditions (e.g., more pay, authority, or self-direction). Voluntary employer changes also are likely to be positively associated with objective measures of career success (Feldman \& Ng, 2007). Assuming that these more beneficial preretirement work situations make it more intrinsically rewarding for older workers to contribute to and invest in their work, all three forms of career mobility can be expected to be related to lower levels of preretirement work disengagement. We hypothesize that position changes - both without (Hypothesis 2) and with promotion (Hypothesis 3) - and employer changes (Hypothesis 4) result in a lower level of preretirement work disengagement.

In discussions about the labor force participation of older workers, lifelong learning is often perceived as one of the key policy measures to keep workers employed until older ages (OECD, 2006). Participation in training will extend the knowledge and skills of workers (i.e., their human capital), which can be expected to positively affect their preretirement work situation. As outlined by the OECD (2006) "workers who have ample opportunities midcareer for upgrading their skills or for learning new skills may be better placed in terms of labor market outcomes when older than those who had few opportunities (p.120).” When 
assuming that these better labor market outcomes make work activities and investments more beneficial to older workers, participation in training can be expected to result in a lower level of preretirement work disengagement. Moreover, when arguing from a social exchange perspective, an analogous prediction can be made. If organizations invest in and support their employees, for example by offering training, this creates an obligation for employees to repay the organization (Armstrong Stassen \& Ursel, 2009). One form of repayment might be an increase in work activities, motivation, and investments. We hypothesize that participation in training during the career results in a lower level of preretirement work disengagement (Hypothesis 5).

The way in which older workers approach retirement cannot be seen in isolation from their health situation. Health problems might constrain work capacities and might increase the relative value of leisure time. One way in which older workers can deal with changing opportunity structures due to declining health is by retiring. Poor health is often found to be an important predictor of early retirement (See for reviews Feldman, 1994; Wang \& Shultz, 2010) and some older workers seem to perceive retirement as a health investment strategy (Henkens, 1999). Another way in which older workers can cope with declining health is by decreasing their work activities and investments. Their more constrained work capacities and increased relative valuation of leisure time can be expected to result in reduced work hours, less work motivation, and fewer investments in development and training. Consequently, a declining health situation is hypothesized to be related to a higher level of preretirement work disengagement (Hypothesis 6). 


\section{METHODS}

\section{Sample}

This study is based on panel data collected in the Netherlands. In 2001 (wave 1) data were collected among (1) a random sample of older civil servants aged 50 years and over and (2) all workers aged 50 years and over of three large Dutch multinational private-sector organizations that are active in the fields of information and communication technology, retail, and manufacturing. A mail questionnaire was sent to 3,899 older workers; in total 2,403 questionnaires were completed (response rate 62\%). A follow-up study was conducted in 2006-2007 among participants of the first wave. There was some attrition due to company takeovers $(\mathrm{N}=116)$, mortality $(\mathrm{N}=44)$ and untraceable participants $(\mathrm{N}=4)$. A total of 2,239 questionnaires were mailed out, of which 1,678 were returned (response rate 75\%).

First, by analyzing the wave 1 cross-section of the data, we examine whether variation in the level of preretirement work disengagement between individuals can be explained by differences in their future career and mid-career experiences (i.e., experiences before age 50). Given that the retrospective questions on mid-life experiences were asked during wave 2, the base sample for the cross-sectional analyses consists of all 1,678 respondents who completed the survey during both waves of data collection. Cases who lacked critical information on the wave 1 preretirement work disengagement measure $(\mathrm{N}=13)$ or who did not answer any of the central questions regarding mid-life experiences $(\mathrm{N}=31)$ were excluded from the sample, resulting in an analytic sample of 1,634 older workers.

Second, by using the panel structure of the data, we examine whether changes in the level of preretirement work disengagement between waves 1 and 2 can be explained by differences in the proximity to anticipated retirement and late-career experiences (i.e., experiences between waves 1 and 2). Given that work disengagement can only be observed among older individuals who are still working, the base sample for the panel analyses consists 
of 688 respondents who were still working at wave 2. Respondents who lacked critical information on the wave 2 preretirement work disengagement measure $(\mathrm{N}=1)$, who already reached the public pension age of $65(\mathrm{~N}=2)$ and who did not answer any of the central questions regarding late-career experiences $(\mathrm{N}=33)$ were eliminated from the sample. This results in an analytic sample of 652 older workers.

\section{Measures}

\section{Dependent variable}

During both waves of data collection, employed respondents were asked about their level of preretirement work disengagement by means of six Likert items with five answer categories (1=completely agree to $5=$ completely disagree). These items capture a variety of work activities and investments that older workers might reduce in the preretirement period: work hours, training, taking up new responsibilities, motivation, and actions to keep up with the latest developments in the field (see Table 1). To check whether these items measure one concept, we submitted the data to exploratory factor analyses using the principal factors method. At both wave 1 and wave 2, only one factor was extracted with an eigenvalue greater than 1.00, suggesting that the items measure one underlying concept. The scale was constructed by calculating the mean score of the available items. High scale scores represent high disengagement levels. The Cronbach's alpha of the scale is 0.71 at wave 1 and 0.72 at wave 2, which is reasonable (Nunnally, 1978).

\section{[TABLE 1 ABOUT HERE]}




\section{Independent variables}

Proximity to retirement - In the cross-sectional models 'age at baseline' is used as proxy for time-left to retirement. In the panel models, a more direct measure is used, namely the difference between the planned retirement age reported at wave 1 (based on the question “at which age do you want to stop working?”) and the respondent's age at wave 2. Proximity to retirement was categorized in one-year increments up to six years, whereby workers who were six or more years away from their planned retirement age form the reference group. Workers who 'did not know yet' when to retire were grouped into a separate category, as well as workers who had passed their planned retirement age at wave 2. Proximity to retirement was not included in the cross-sectional models since this is an endogenous variable (i.e., the individually planned retirement age is affected by the disengagement process).

Past career experiences - Career experiences in mid-life were measured by two questions that asked respondents to indicate for several life experiences (position change, promotion, employer change, additional training, and severe health problems) whether they had these experiences before age 40 and between ages 40 and 50. We constructed a dummy variable per life experience, indicating whether the employee had had the particular experience before age 50 (i.e., answer 'yes' to one or both of the questions). Given that position changes and promotions often coincide these experiences were combined into a three-category variable: (1) no change of position (reference group); (2) changed positions without promotion; (3) changed positions by making promotion. Late-career experiences between waves 1 and 2 were measured by two types of questions. First, respondents were asked to indicate at which age they experienced a change of position, promotion, employer change, and work-related training the last time. Based on the reported ages, we constructed a dummy variable per life experience, indicating whether the employee had had this specific experience between the waves of data collection (i.e., reported age was higher than age at 
wave 1). Also here the responses to the position change and promotion items were combined into a three-category variable. Second, health changes between the waves of data collection were studied by the question "has your health changed over the last five years?" ( 1 = yes, deteriorated much to $5=$ yes, greatly improved). A dummy variable was constructed indicating whether or not the health situation of the respondent deteriorated. All questions on past career experiences were measured at wave 2 .

Control variables - Some basic demographic and career characteristics are controlled for in the analyses. First, we control for the gender of the respondent ( $0=$ man, $1=$ woman). The respondent's age of entering the labor market was measured by the question "at what age did you start working?.” Reported occupations were coded into SBC-1992 occupational codes (Statistics Netherlands, 2001) and categorized into two groups: nonmanual work $(=0)$ and manual work (= 1). Based on the question "Do you have a supervisory position? ( $1=$ No to 4 = Yes, I supervise more than 20 persons)”, we measured whether $(=1)$ or not $(=0)$ the respondent has a supervisory position. All control variables were measured at wave 1 . The descriptive statistics of the independent and control variables are presented in Table 2.

\section{[TABLE 2 ABOUT HERE]}

\section{Analyses}

Linear regression models were estimated for testing our hypotheses. To examine betweenindividual differences in preretirement work disengagement (cross-sectional analyses), preretirement work disengagement at wave 1 is regressed on age, mid-career experiences, and control variables. To examine changes in work disengagement over time (panel analyses), the value of preretirement work disengagement at wave 2 is predicted by the value of preretirement work disengagement at wave 1, proximity to planned retirement age, late-career 
experiences, and control variables. In these conditional change models, the coefficients can be interpreted as the effects of the independent variables on the change in preretirement work disengagement between waves 1 and 2, controlling for initial disengagement levels at wave 1 (Finkel, 1995).

For the panel analyses, we only observe preretirement work disengagement levels for older individuals who are still working at wave 2. However, whether respondents are still working, might be the result of a selective process. To prevent biased conclusions, we estimated Heckman maximum likelihood selection models, consisting of two stages. First, selection into the sample was predicted on the basis of all independent variables included in the cross-sectional models and measures of the preretirement financial situation (pension build-up, wealth, and the financial dependence of children). The statistically significant results of the Wald test of independent equations suggest there indeed might be sample selection bias. Second, the probability of remaining in the panel (converted to Lambda) was calculated from the parameter estimates of the first model and was included in the model for predicting preretirement work disengagement at wave 2. Selection models are not without problems, however, they are the best option so far in the absence of quasi-experiments $(\mathrm{Fu}$, Winship, \& Mare, 2004).

We used robust standard errors allowing for intradepartmental correlation in the analyses, to take care of the multilevel structure of the data (employees of four organizations nested in organizational departments). To control for potential organizational-level effects, organizational dummy variables were included in the models (cf. Damman et al., 2011).

\section{RESULTS}

In Table 3 the results of multivariate linear regression analyses to explain differences in preretirement work disengagement at wave 1 are presented. Table 4 presents the results of the 
conditional change models that are estimated to explain changes in preretirement work disengagement between waves 1 and 2 .

Cross-sectional models: Explaining differences in preretirement work disengagement The positive effect of the respondent's age at baseline in Model 1a - used as a proxy for timeleft to retirement - is in line with hypothesis 1 (see Table 3). It shows that employees who are closer to the public pension age of 65 are more disengaged from their work than their younger counterparts. All control variables are related to preretirement work disengagement as well. Women are less disengaged from work than men. For employees who entered the labor market relatively late also lower preretirement work disengagement levels are found. Workers performing manual labor show higher levels of preretirement work disengagement, whereas supervisors appear to be less disengaged than employees in non-supervisory positions.

In Model 1b mid-career experiences are added to the model. Older workers who made promotion and who changed employers in mid-career are less disengaged from their work in the preretirement period, compared to their non-mobile counterparts. These findings support hypotheses 3 and 4. No support is found for hypothesis 2: older workers who changed positions in mid-life - without making promotion - do not differ from those who did not change positions. As expected in hypothesis 5, employees who participated in additional training in their mid-careers are less disengaged, compared to those who did not do so. Midlife health problems, as predicted in hypothesis 6, are associated with higher levels of preretirement work disengagement.

\section{[TABLE 3 ABOUT HERE]}


Panel models: Explaining changes in preretirement work disengagement over time

Between waves 1 and 2, the level of preretirement work disengagement increased among the studied older workers. The mean scale score of the respondents in the second wave sample is 2.50, whereas their mean score was 2.35 at the first wave of data collection $(t(651)=6.18, p$ $<.001$ ). For about $25 \%$ of the employees disengagement levels increased more than one standard deviation $(\mathrm{SD}$ (wave 1)=0.62). About $10 \%$ of the workers experienced a decrease in disengagement of more than one standard deviation. The preretirement work disengagement scores of both waves are strongly correlated, $r(650)=.58, p<.001$.

In model 2a (Table 4) the effects of time-left to (individual) retirement on preretirement work disengagement are reported, when controlling for the wave 1 preretirement work disengagement level. In line with hypothesis 1, the results show that the closer employees got to their planned retirement age between the waves of data collection, the larger their increase in preretirement work disengagement is. Compared to the reference group ( $\geq 6$ years proximate to retirement), especially older workers who got relatively close to their planned retirement age (0-2 years left-to retirement) showed larger increases in preretirement work disengagement over time. However, the results suggest that already a number of years prior to retirement work disengagement levels start to increase. Workers who have passed their planned retirement age also showed relatively large increases in work disengagement. The coefficients for the control variables gender, age of entering the labor market, and type of work are not statistically significant. Persons in a non-supervisory position at wave 1 showed larger increases in work disengagement over time, compared to those having a supervisory position.

In model $2 \mathrm{~b}$ late-career experiences are added to the model. Both late-career promotions and employer changes are negatively related to preretirement work disengagement, which is in line with hypothesis 3 and 4. Compared to those who did not have 
these experiences, the disengagement levels of older workers who were promoted or changed employers decreased over the studied period. The coefficient for those who changed positions - without promotion - is not statistically significant; no support is found for hypothesis 2 . As predicted in hypothesis 6, deterioration of health is found to be associated with a larger increase of work disengagement. The effect of late-career participation in training proved to be not statistically significant. However, if we do not control for position changes, the effect of training is statistically significant but still relatively small.

\section{[TABLE 4 ABOUT HERE]}

\section{DISCUSSION}

The transition from work to retirement is a complex long-term process. This study clearly shows that the preretirement work disengagement process already starts a couple of years before older workers retire and steadily increases when workers get closer to retirement. Also for workers who have passed their planned retirement age, relatively large increases in work disengagement were found. So, when approaching planned retirement older workers do not only perceive their job as more burdensome (Ekerdt \& DeViney, 1993) and increase their frequency of thinking, talking and reading about retirement (Ekerdt et al., 2000; Evans et al., 1985), but also decrease their work investments, activities and motivation. Besides contributing to the preretirement process literature, these findings contribute to the career literature by showing that during late-careers specific forces (i.e., looming retirement) start to play a role that are of little importance during other career stages. Whereas age has been studied extensively to explain job attitudes and behaviors over the life course (See metaanalyses by Ng \& Feldman, 2008; Ng \& Feldman, 2010), the temporal dimension of 'time-left to retirement' is an important - but yet understudied - factor for explaining late-career job 
attitudes and behaviors. From a policy perspective the findings are relevant as well. Many western countries are involved in reforms that raise the retirement age. Increasing numbers of older adults will be forced to work longer than they originally had planned. This holds in particular for countries as the Netherlands that were characterized by a strong early exit culture (De Vroom, 2004). Our results suggest that unmet retirement plans might increase disengagement and point to a challenge for organizations to keep their older workers motivated and engaged.

Late careers are not necessarily characterized by a unidirectional pathway of disengagement from work. This study shows that, even though for many studied workers the level of work disengagement increased over the studied period, for others disengagement levels decreased. As proposed in the life course perspective, individual development during late-careers seems to be a multidirectional process (Settersten, 2003), reflecting both upward and downward dynamics in disengagement levels. Career experiences appear to play an important role in explaining these late-career dynamics. Our findings show that promotions and employer changes slow down the preretirement work disengagement process. Health problems appear to accelerate the disengagement process. Interestingly, positional changes that were not accompanied with upward mobility were neither found to be related to work disengagement levels at baseline nor to changes in disengagement during late careers. This raises the question: Why do some types of mobility result in a decrease of work disengagement, while other types do not affect the preretirement process? Probably this is because the various types of mobility are associated with different levels of change in older workers' opportunity structures (i.e., their work content and context). Whereas the opportunity structure will change much if a worker switches employers or makes promotion, a position change might only reflect a limited change of the opportunity structure. Studying 
what exactly causes the different effects of the career transitions would be an important venue for future research.

We also found no support for the hypothesis that participation in training results in a lower level of preretirement work disengagement. Even though in the cross-sectional models participation in additional mid-career training is related to lower levels of preretirement work disengagement, late-career participation in work-related training did not slow down work disengagement over the studied period. That the panel estimates found no effect while the cross-sectional models did find support may partly reflect selection effects. Those who are least disengaged are most likely to be offered training. We also note that the effect in the panel model is significant (albeit small) if promotion is not controlled for. These findings might indicate that training only reduces work disengagement if it coincides with getting a better job by means of a promotion. In light of current discussions on lifelong learning it should be noted that our study used a rather crude measure of training participation, which did not differentiate between types of training, who initiated the training, and training intensity.

When interpreting the findings of this study, some limitations should be kept in mind. First, in the analyses we assumed that retirement plans have been stable over the studied period. In retirement literature it is well-known, however, that retirement plans change over time (Ekerdt \& DeViney, 1993; Wong \& Hardy, 2009). For example, changes in the individual's financial opportunity structure could have resulted in postponement of planned retirement. If this is the case we have underestimated the effects of proximity to retirement on changes in disengagement. Second, the studied mid- and late-career variables are based on rather broad retrospective questions. Although the availability of the information on prior career experiences is an important strength of our data, not all potential forms of mobility were measured (e.g., demotion) and recall or memory-bias effects cannot be ruled out. Nevertheless, the low incidence and salience of the studied career experiences might have 
positively influenced recall accuracy (Eisenhower, Mathiowetz, \& Morganstein, 1991). Third, even though the selected organizations are highly diverse in their branches of industry and the studied employees vary substantially on important variables like career experiences, work characteristics and health, the workers in the studied sample are not representative of all Dutch older workers. The selected organizations are all large organizations, in which career timetables are generally prominent and the topicality of retirement high (Ekerdt et al., 2000). This might limit the generalizability of the findings to self-employed older workers, or those who work in smaller organizations.

Despite these limitations, this study clearly shows that work disengagement in preretirement years is both dependent upon past career experiences and the anticipated timeleft in the labor market. As the life course proposition of lifelong development suggests (Settersten, 2003), for achieving a comprehensive understanding of the retirement process the past, present, and future should be taken into account. Both the "time-in-state", and the anticipated "time-left-in-state" (Ekerdt \& DeViney, 1993, p.S40) - whether this reflects the time-left in the labor force or more broadly the time-left in life (Van Solinge \& Henkens, 2010) - will shape the attitudes and actions of individuals. Not only for studying the preretirement process, but also for studying the retirement act itself and postretirement adaptation, it is highly relevant to take this lifelong nature of individual development into account. 


\section{REFERENCES}

Adams, G. A., \& Rau, B. L. (2011). Putting off tomorrow to do what you want today. Planning for retirement. American Psychologist, 66(3), 180-192.

Allen, T. D., Russell, J. E. A., Poteet, M. L., \& Dobbins, G. H. (1999). Learning and development factors related to perceptions of job content and hierarchical plateauing. Journal of Organizational Behavior, 20(7), 1113-1137.

Armstrong Stassen, M., \& Ursel, N. D. (2009). Perceived organizational support, career satisfaction, and the retention of older workers. Journal of Occupational and Organizational Psychology, 82(1), 201-220.

Atchley, R. C. (1976). The sociology of retirement. New York: John Willey and Sons.

Beehr, T. A. (1986). The process of retirement: A review and recommendations for future investigation. Personnel Psychology, 39(1), 31-55.

Bown-Wilson, D., \& Parry, E. (2009). Career plateauing in older workers: Contextual and psychological drivers. In S. G. Baugh \& S. E. Sullivan (Eds.), Maintaining Focus, Energy, and Options Over the Career Charlotte, NC: Information Age Publishing, Inc.

Damman, M., Henkens, K., \& Kalmijn, M. (2011). The impact of midlife educational, work, health, and family experiences on men's early retirement. The Journals of Gerontology Series B: Psychological Sciences and Social Sciences, 66(5), 617-627.

De Vroom, B. (2004). The shift from early to late exit: Changing institutional conditions and individual preferences. The case of the Netherlands. In T. Maltby \& B. De Vroom \& M. L. Mirabile \& E. Overbye (Eds.), Ageing and the transition to retirement. A comparative analysis of European welfare states (pp. 120-154). Aldershot: Ashgate.

Eisenhower, D., Mathiowetz, N. A., \& Morganstein, D. (1991). Recall error: Sources and bias reduction techniques. In P. P. Biemer \& R. M. Groves \& L. E. Lyberg \& N. A. 
Mathiowetz \& S. Sudman (Eds.), Measurement errors in surveys (pp. 127-144). Hoboken, New Jersey: Wiley.

Ekerdt, D. J., \& DeViney, S. (1993). Evidence for a preretirement process among older male workers. Journal of Gerontology: Social Sciences, 48B(2), S35-S43.

Ekerdt, D. J., Kosloski, K., \& DeViney, S. (2000). The normative anticipation of retirement by older workers. Research on Aging, 22(1), 3-22.

Elder, G. H., \& Johnson, M. K. (2003). The life course and aging. Challenges, lessons, and new directions. In R. A. Settersten (Ed.), Invitation to the life course. Towards new understandings of later life (pp. 49-81). New York: Baywood.

Evans, L., Ekerdt, D. J., \& Bossé, R. (1985). Proximity to retirement and anticipatory involvement: Findings from the Normative Aging Study. Journal of Gerontology, 40(3), 368-374.

Feldman, D. C. (1994). The decision to retire early: A review and conceptualization. Academy of Management Review, 19(2), 285-311.

Feldman, D. C., \& Ng, T. W. H. (2007). Careers: Mobility, embeddedness, and success. Journal of Management, 33(3), 350-377.

Finkel, S. E. (1995). Causal analysis with panel data. London: Sage.

Fu, V. K., Winship, C., \& Mare, R. D. (2004). Sample selection bias models. In M. Hardy \& A. Bryman (Eds.), Handbook of data analysis (pp. 409-430). London: Sage.

Han, S. K., \& Moen, P. (1999). Clocking out: Temporal patterns of retirement. American Journal of Sociology, 105(1), 191-236.

Hank, K. (2004). Effects of early life family events on women's late life labour market behaviour: An analysis of the relationship between childbearing and retirement in western Germany. European Sociological Review, 20(3), 189-198. 
Hayward, M. D., Friedman, S., \& Chen, H. (1998). Career trajectories and older men's retirement. Journal of Gerontology: Social Sciences, B53(2), S91-S103.

Henkens, K. (1999). Retirement intentions and spousal support: A multi-actor approach. Journal of Gerontology: Social Sciences, 54B, S63-S74.

Henkens, K., \& Van Solinge, H. (2003). Het eindspel: werknemers, hun partners en leidinggevenden over uittreding uit het arbeidsproces. Assen: Van Gorcum/Stichting Management Studies.

McEvoy, G. M., \& Blahna, M. J. (2001). Engagement or disengagement? Older workers and the looming labor shortage. Business Horizons, 44(5), 46-52.

Moen, P., Sweet, S., \& Swisher, R. (2005). Embedded career clocks: The case of retirement planning. Advances in Life Course Research, 9, 237-265.

Ng, T. W. H., \& Feldman, D. C. (2008). The relationship of age to ten dimensions of job performance. Journal of Applied Psychology, 93(2), 392-423.

Ng, T. W. H., \& Feldman, D. C. (2010). The relationships of age with job attitudes: A metaanalysis. Personnel Psychology, 63(3), 677-718.

Nunnally, J. C. (1978). Psychometric theory. New York: McGraw-Hill.

OECD. (2006). Live longer, work longer. Ageing and employment policies. Paris: Organisation of Economic Co-operation and Development.

Raymo, J. M., Warren, J. R., Sweeney, M. M., Hauser, R. M., \& Ho, J.-H. (2011). Precarious employment, bad jobs, labor unions, and early retirement. The Journals of Gerontology Series B: Psychological Sciences and Social Sciences, 66B(2), 249-259.

Settersten, R. A. (2003). Propositions and controversies in life-course scholarship. In R. A. Settersten (Ed.), Invitation to the life course. Towards new understandings of later life (pp. 15-48). New York: Baywood. 
Shultz, K. S., \& Wang, M. (2011). Psychological perspectives on the changing nature of retirement. American Psychologist, 66(3), 170-179.

Singh, G., \& Verma, A. (2003). Work history and later life labor force participation: Evidence from a large telecommunications firm. Industrial and Labor Relations Review, 56(4), 669-715.

Statistics Netherlands. (2001). Standaard beroepenclassificatie. Editie 2001 [Standard occupational classification. Edition 2001]. Voorburg/Heerlen: Statistics Netherlands.

Super, D. E. (1957). The psychology of careers. An introduction to vocational development. New York: Harper \& Brothers.

Szinovacz, M. E. (2003). Contexts and pathways: Retirement as institution, process, and experience. In G. A. Adams \& T. A. Beehr (Eds.), Retirement. Reasons, Processes and Results (pp. 6-52). New York: Springer.

Van Solinge, H., \& Henkens, K. (2005). Couples' adjustment to retirement: A multi-actor panel study. Journal of Gerontology: Social Sciences, 60B(1), S11-S20.

Van Solinge, H., \& Henkens, K. (2010). Living longer, working longer? The impact of subjective life expectancy on retirement intentions and behaviour. European Journal of Public Health, 20(1), 47-51.

Wang, M., \& Shultz, K. S. (2010). Employee retirement: A review and recommendations for future investigation. Journal of Management, 36(1), 172-206

Wong, J. D., \& Hardy, M. A. (2009). Women's retirement expectations: How stable are they? The Journals of Gerontology Series B: Psychological Sciences and Social Sciences, 64B(1), 77-86. 
Table 1 Descriptive statistics of preretirement work disengagement items, 2001 and 20062007

\begin{tabular}{|c|c|c|c|c|c|c|}
\hline \multirow[t]{2}{*}{ Items (translated from Dutch) } & \multicolumn{3}{|c|}{ Wave 1 (2001) } & \multicolumn{3}{|c|}{ Wave 2 (2006-2007) } \\
\hline & $\begin{array}{l}\text { mean } \\
\text { (sd) }\end{array}$ & $\mathrm{N}$ & $\begin{array}{l}\text { Item- } \\
\text { test } \\
\text { correla- } \\
\text { tion } \\
\end{array}$ & $\begin{array}{l}\text { mean } \\
\text { (sd) }\end{array}$ & $\mathrm{N}$ & $\begin{array}{l}\text { Item- } \\
\text { test } \\
\text { correla- } \\
\text { tion }\end{array}$ \\
\hline $\begin{array}{l}\text { I do not keep up as well with the } \\
\text { latest developments in my field } \\
\text { as I did five years ago } \\
\text { (reversed) }\end{array}$ & $\begin{array}{l}2.82 \\
(1.16)\end{array}$ & 1627 & 0.67 & $\begin{array}{l}2.84 \\
(1.14)\end{array}$ & 646 & 0.68 \\
\hline $\begin{array}{l}\text { I think they should assign new } \\
\text { responsibilities to younger } \\
\text { persons (reversed) }\end{array}$ & $\begin{array}{l}2.89 \\
(1.08)\end{array}$ & 1628 & 0.65 & $\begin{array}{l}2.76 \\
(1.10)\end{array}$ & 647 & 0.64 \\
\hline $\begin{array}{l}\text { I am still as motivated for my } \\
\text { work as two years ago }\end{array}$ & $\begin{array}{l}2.43 \\
(1.07)\end{array}$ & 1629 & 0.64 & $\begin{array}{l}2.24 \\
(1.10)\end{array}$ & 647 & 0.64 \\
\hline $\begin{array}{l}\text { They should no longer ask me to } \\
\text { participate in new courses } \\
\text { (reversed) }\end{array}$ & $\begin{array}{l}2.56 \\
(1.17)\end{array}$ & 1631 & 0.67 & $\begin{array}{l}2.79 \\
(1.22)\end{array}$ & 651 & 0.68 \\
\hline $\begin{array}{l}\text { I use every possibility to reduce } \\
\text { the number of hours I work } \\
\text { (reversed) }\end{array}$ & $\begin{array}{l}2.37 \\
(1.02)\end{array}$ & 1630 & 0.61 & $\begin{array}{l}2.32 \\
(1.07)\end{array}$ & 651 & 0.59 \\
\hline $\begin{array}{l}\text { I think it is important to keep } \\
\text { myself informed of new } \\
\text { developments in my field }\end{array}$ & $\begin{array}{l}2.10 \\
(0.80)\end{array}$ & 1627 & 0.61 & $\begin{array}{l}2.04 \\
(0.69)\end{array}$ & 650 & 0.70 \\
\hline $\begin{array}{l}\text { Scale preretirement work } \\
\text { disengagement }{ }^{b}\end{array}$ & $\begin{array}{l}2.53 \\
(0.67)\end{array}$ & 1634 & & $\begin{array}{l}2.50 \\
(0.69)\end{array}$ & 652 & \\
\hline
\end{tabular}


Table 2 Descriptive statistics of independent variables

\begin{tabular}{lrrr}
\hline Variables & Mean & SD & Coding \\
\hline Cross-sectional models (N=1634) & & & \\
& & & \\
Anticipated future career & & & \\
$\quad$ Age at baseline & 54.09 & 2.85 & $50-64$ \\
Mid-career experiences (< age 50) & & & \\
$\quad$ Change of position (ref: no change) & & & \\
$\quad$ Position change - no promotion & 0.08 & 0.27 & $0-1$ \\
$\quad$ Position change - promotion & 0.76 & 0.43 & $0-1$ \\
$\quad$ Employer change & 0.41 & 0.49 & $0-1$ \\
$\quad$ Additional training & 0.60 & 0.49 & $0-1$ \\
$\quad$ Severe health problems & 0.19 & 0.39 & $0-1$ \\
Control variables & & & \\
$\quad$ Gender: woman & 0.25 & 0.43 & $0-1$ \\
$\quad$ Age entering labor market & 18.95 & 4.78 & $12-53$ \\
$\quad$ Type of work: manual & 0.11 & 0.31 & $0-1$ \\
$\quad$ Position: supervisory & 0.27 & 0.45 & $0-1$ \\
\hline
\end{tabular}

Panel models $(N=652)$

$\begin{array}{llll}\text { Preretirement work disengagement W1 } & 2.35 & 0.62 & 1-4.5\end{array}$

Anticipated future career

Time-left to retirement (ref: 6 or more yrs)

Older than planned retirement age 1

$0.10 \quad 0.29 \quad 0-1$

Prox. to planned retirement age: 0

$0.09 \quad 0.29 \quad 0-1$

Prox. to planned retirement age: 1

$0.13 \quad 0.34 \quad 0-1$

Prox. to planned retirement age: 2

$0.12 \quad 0.33 \quad 0-1$

Prox. to planned retirement age: 3

$0.13 \quad 0.33 \quad 0-1$

Prox. to planned retirement age: $4 \quad 0.16 \quad 0.37 \quad 0-1$

Prox. to planned retirement age: $5 \quad 0.09 \quad 0.28 \quad 0-1$

Don't know

$0.07 \quad 0.26 \quad 0-1$

Late-career experiences (between waves 1 \& 2)

Change of position (ref: no change)

Position change - no promotion

$0.18 \quad 0.39 \quad 0-1$

Position change - promotion

$0.17 \quad 0.37 \quad 0-1$

Employer change

$0.07 \quad 0.26 \quad 0-1$

Participation in training

$0.64 \quad 0.48 \quad 0-1$

Health decline

$\begin{array}{lll}0.31 & 0.46 \quad 0-1\end{array}$

Control variables

Gender: woman

$0.27 \quad 0.45 \quad 0-1$

Age entering labor market

$19.15 \quad 4.76 \quad 13-50$

Type of work: manual

$0.09 \quad 0.28$

$0-1$

Position: supervisory

$0.29 \quad 0.45$

$0-1$ 
Table 3 Cross-sectional models of preretirement work disengagement: coefficients and robust standard errors

\begin{tabular}{|c|c|c|c|c|}
\hline & \multicolumn{2}{|l|}{ Model 1a } & \multicolumn{2}{|l|}{ Model 1b } \\
\hline & Coef. & SE & Coef. & SE \\
\hline Constant & $1.89 * * *$ & 0.29 & $2.10 * * *$ & 0.30 \\
\hline \multicolumn{5}{|l|}{ Anticipated future career } \\
\hline Age at baseline & $0.02 * * *$ & 0.00 & $0.02 * * *$ & 0.00 \\
\hline \multicolumn{5}{|l|}{ Mid-career experiences (< age 50) } \\
\hline \multicolumn{5}{|l|}{ Change of position (a) } \\
\hline Position change - no promotion & & & -0.10 & 0.07 \\
\hline Position change - promotion & & & $-0.14 * *$ & 0.05 \\
\hline Employer change (b) & & & $-0.06^{*}$ & 0.03 \\
\hline Additional training (b) & & & $-0.17 * * *$ & 0.03 \\
\hline Severe health problems (b) & & & $0.18 * * *$ & 0.05 \\
\hline \multicolumn{5}{|l|}{ Control variables } \\
\hline Gender: woman (c) & $-0.12 *$ & 0.05 & $-0.17 * * *$ & 0.04 \\
\hline Age entering labor market & $-0.01 * *$ & 0.00 & $-0.02 * * *$ & 0.00 \\
\hline Type of work: manual (d) & $0.31 * * *$ & 0.05 & $0.25 * * *$ & 0.05 \\
\hline Position: supervisory (e) & $-0.19 * * *$ & 0.03 & $-0.15 * * *$ & 0.03 \\
\hline $\mathrm{N}$ & 1634 & & 1634 & \\
\hline $\mathrm{F}$ & $25.86 * * *$ & & $26.31 * * *$ & \\
\hline $\mathrm{R}^{2}$ & 0.07 & & 0.11 & \\
\hline
\end{tabular}

Note: In both models, organization is controlled for by including organizational dummy indicators.

Note: Omitted categories are (a) no change of position, (b) no, (c) man, (d) nonmanual work, (e) nonsupervisory position.

$* \mathrm{p}<.05 ; * * \mathrm{p}<.01 ; * * * \mathrm{p}<.001$ 
Table 4 Conditional change models of preretirement work disengagement: coefficients and robust standard errors

\begin{tabular}{lllll}
\hline & $\begin{array}{l}\text { Model 2a } \\
\text { Coef. }\end{array}$ & SE & $\begin{array}{l}\text { Model 2b } \\
\text { Coef. }\end{array}$ & SE \\
\hline \hline & & & & \\
Constant & $1.27^{* * *}$ & 0.12 & $1.44^{* * *}$ & 0.12 \\
Preretirement work disengagement W1 & $0.58^{* * *}$ & 0.04 & $0.53^{* * *}$ & 0.04
\end{tabular}

Anticipated future career

Time-left to retirement (a)

Older than planned retirement age

$\begin{array}{llll}0.31 * * & 0.11 & 0.30^{* *} & 0.11 \\ 0.21^{* *} & 0.07 & 0.22^{* *} & 0.07 \\ 0.32^{* * *} & 0.08 & 0.32 * * * & 0.08 \\ 0.25^{* *} & 0.08 & 0.22^{* *} & 0.07 \\ 0.11 & 0.07 & 0.11 & 0.06 \\ 0.15^{* *} & 0.05 & 0.12 * & 0.05 \\ 0.12 & 0.08 & 0.10 & 0.08 \\ 0.08 & 0.09 & 0.08 & 0.09\end{array}$

Late-career experiences (between waves 1

\& 2)

Change of position (b)

Position change - no promotion

$\begin{array}{ll}-0.07 & 0.06 \\ -0.21 * * * & 0.04 \\ -0.19 * & 0.09 \\ -0.06 & 0.04 \\ 0.19 * * & 0.06\end{array}$

Employer change (c)

Participation in training (c)

Health decline (c)

Control variables

Gender: woman (d)

$-0.10$

$0.07 \quad-0.09$

0.07

Age entering labor market

$-0.01$

$0.01 \quad-0.01$

0.00

Type of work: manual (e)

$-0.01$

$0.10 \quad 0.01$

0.10

Position: supervisory (f)

$-0.14 * *$

0.05

$-0.12 *$

0.05

N (censored/ uncensored)

846/652

$846 / 652$

Wald chi2

$783.11^{* * *}$

$1216.36^{* * *}$

Lambda

$-0.13^{* *}$

$0.05-0.15^{* *}$

0.05

Note: In both models, organization is controlled for by including organizational dummy indicators

Note: Omitted categories are (a) 6 or more years proximate to planned retirement age, (b) no change of position, (c) no, (d) man, (e) nonmanual work, (f) nonsupervisory position.

$* \mathrm{p}<.05 ; * * \mathrm{p}<.01 ; * * * \mathrm{p}<.001$ 